\title{
Öğretmenlerin Eğitime İnanma Düzeylerinin Çeşitli Değişkenler Açısından İncelenmesi*
}

\author{
Analyzing Teachers' Levels of Believing in Education Related \\ to Some Variables
}

\begin{abstract}
Nail YILDIRIM**, Uğur AKIN***
Öz: $\mathrm{Bu}$ araştırmanın amacı, öğretmenlerin eğitime inanma düzeylerini belirlemek ve öğretmenlerin eğitime inanma durumlarının okul kademesi, kıdem, eğitim durumu, yöneticilik yapmış olma, karamsar ya da iyimser olma değişkenlerine göre farklılaşıp farklılaşmadığını incelemektir. Araştırmada, öğretmenlerin Türk eğitim sisteminin amaçlarına ulaşma durumuna ilişsin inançları, genel olarak eğitime inanma olarak kavramlaştırılmıştır. Araştırmaya Tokat'taki kamu ilköğretim ve ortaöğretim okullarında çalışan 546 öğretmen katılmıştır. Veriler, Akın ve Yıldırım (2015) tarafından geliştirilen Öğretmenlerin Eğitime İnanma Düzeyleri Ölçeği (ÖEİDÖ) aracılığıyla toplanmıştır. Ölçek toplumsallaştırma, bireysel farklılıklar, çok yönlü gelişim ve üst öğrenime hazırlama olmak üzere dört alt boyuttan oluşmaktadır. Araştırma sonuçlarına göre, öğretmenler eğitimin toplumsallaştırma, çok yönlü gelişim ve üst öğrenime hazırlama ile ilgili amaçlarına ulaşıldığına orta düzeyde inanırken, bireysel farklılıklara ilişkin amaçlara ulaşıldığına çok az inanmaktadır. Tüm boyutlar birlikte değerlendirildiğinde öğretmenlerin en çok öğrencilerin üst öğrenime en iyi biçimde hazırlandığına inandıkları görülmektedir. Bunun yanında, öğretmenler öğrencilere firsat eşitliği sağlandığına en az düzeyde inanmaktadırlar. İlkokul öğretmenleri eğitimin belirlenen amaçlara ulaştığına ortaokul ve lise öğretmenlerine göre daha fazla inanmaktadır. Sonuçlar, kıdemi 20 yıldan fazla olan öğretmenlerin eğitimin çok yönlü gelişimi sağlama ve üst öğrenime hazırlama ile ilişkilendirilen amaçlarına ulaştığına diğer öğretmenlerden daha fazla inandıklarını göstermektedir. Eğitim durumuna göre anlamlı farklılık bulunmazken; yöneticilik deneyimi olan ve kendisini daha çok iyimser olarak tanımlayan öğretmenlerin eğitimin amacına ulaştığına daha fazla inandıkları tespit edilmiştir.
\end{abstract}

Anahtar Kelimeler: Öğretmen, Türk eğitim sistemi, eğitime inanma

\begin{abstract}
The aim of this study was to determine the teachers' level of believing in the education and analyze this based on their level of school, seniority, level of education, having experience as an administrator, and having a pessimistic or an optimistic character. Teachers' belief that the Turkish education system achieves its set objectives was conceptualized generally as believing in education. Five hundred and forty-six teachers working in public primary and secondary schools in Tokat participated in the survey. The data were collected using the Teachers' Level of Believe in Education Scale (TLBES) developed by Akın and Yildırım (2015). The scale is composed of four dimensions, including socialization, individual differences, multi-faceted development, and preparing to upper education. According to the results, teachers believe that the education achieves its socialization, multi-faceted development, and preparing to upper education at medium level while they hardly believe that the objective around individual differences is achieved. When all dimensions are assessed together, the teachers believe the most that the students are prepared for upper education in the best possible way. Moreover, teachers believe that students are given equal opportunities at the minimum level. Primary school teachers believe that the education achieves its set objectives more than secondary school and high school teachers. The results show that teachers with more than 20 years of seniority believe that the education achieves its objectives of providing a multi-faceted development and preparation for upper education more than other teachers. While no significant difference is found with respect to the level of education, teachers who have managerial experience and who define themselves as more optimistic believe that the education achieves its aim more than others.
\end{abstract}

Keywords: Teacher, Turkish education system, believing in education

*Bu araştırma, 11. Ulusal Eğitim Yönetimi Kongresi’nde sözlü bildiri olarak sunulmuştur.
**Doç. Dr., Gaziosmanpaşa Üniversitesi, Eğitim Fakültesi, Tokat-Türkiye, e-posta. nail.yildirim@gop.edu.tr
***Yrd. Doç. Dr., Gaziosmanpaşa Üniversitesi, Eğitim Fakültesi, Tokat-Türkiye, e-posta. akinuur@gmail.com 


\section{Giriş}

Dünyanın farklı bölgelerindeki çok çeşitli kültürlerde, yapılan işe inanma ile performans arasındaki kuvvetli ilişkiyi vurgulayan birçok özlü söze rastlamak mümkündür. $\mathrm{Bu}$ özlü sözlerde özetle, başarmanın inanmakla mümkün olabileceği belirtilmekte, bu düşünce neredeyse evrensel olarak kabul görmektedir. İnanmakla başarmak arasındaki bu ilişki, örgütler açısından da önemle üzerinde durulması gereken bir konu olmalıdır. Çünkü çalışanların örgütte yapılan işin belirlenen amaçlara ulaşmaya hizmet ettiğine inanmaları, onların performanslarını olumlu yönde etkileyebilir. Bu açıdan, öğretmenlerin eğitim uğraşının belirlenen amaçlara ulaştığına inanmalarının araştırmacıların üzerinde durması gereken önemli bir çalışma alanı olduğu düşünülebilir.

İnanmak, yaşama yönelik bir bakış açısı (Ok, 2009), evrensel bir kabul (Grünberg, 2005) olarak değerlendirilebilir. İnanmak tutumları, tutumlar duyguları, duygularsa eylemleri belirlemektedir (Bat1, 2016). Öğretmenler inandıklarında öğrenci öğrenmesini olumlu yönde etkileyebilmektedir (Weber ve Omotani, 1984). Öğretmen sınıfına girdiğinde işleyeceği dersin ve yapacağı etkinliklerin bir amaca hizmet ettiğine öncelikle kendisi inanmalıdır. Böylelikle kendi motivasyonunu sağlayacak öğretmen, ancak bundan sonra öğrenciyi derse ve etkinliklere katılmaya motive edebilecektir. Çünkü yapacağı işe kendisi inanmayan öğretmenin öğrenciyi inandırması ve istenilen eğitim-öğretim atmosferini oluşturması zor görünmektedir.

Eğitime inanmanın bir yönü de öğretmenlik mesleğinin niteliği ile ilgili olarak ele alınabilir. Argon ve Ertürk (2013), öğretmenlerin yaptıkları işin saygın ve yapılmaya değer önemli bir iş olduğuna inanmalarının içsel motivasyonlarının yükselmesinde önemli bir etken olarak görüldügünü belirtmektedir. Van Veen ve Sleegers'e (2006) göre de öğretmenlerin mesleklerine ilişkin bakış açılarının genel iyi olma durumları üzerinde önemli etkileri vardır. Hargreaves'in (1998) de belirttiği gibi, iyi öğretmenlik olumlu duygularla yapılabilmektedir. Oysa araştırmalar Türkiye'de daha hizmet öncesinde öğretmen adaylarının genel olarak Türk eğitim sistemine yönelik olumsuz algılarının bulunduğunu göstermektedir (Kasapoğlu, 2016; Kiraz ve Dursun, 2015). Benzer biçimde okul yöneticileri de eğitim sisteminde yenileşme çabalarının iyi yönetilemediğini düşünmekte ve bir anlamda yapılan işin ve gösterilen çabaların amacına ulaştığına inanmamaktadır (Akın, 2016).

Alanyazında eğitime inanma biçiminde bir kavramlaştırmaya rastlanmamıştır. İnanma konusu daha çok eğitim inançları biçiminde ele alınmıştır. Eğitim inançları, eğitimle ilgili anlayışlar, tahminler ve önermelerdir (Denessen, 2000, Akt: Tondeur, Hermans, Van Braak ve Valcke, 2008). Eğitim inançları eğitim felsefesine dayalı olarak oluşmakta ve öğretmenlerin eğitim hakkındaki görüş ve inanışları sundukları eğitimin de belirleyicisi olmaktadır (Yılmaz, Altınkurt ve Çokluk, 2011). Öğretmenlerin seçimleri ve eylemlerini eğitim inançları şekillendirmektedir (Quinlan, 1997). Bu nedenle, öğretmenlerin inançlarının incelenmesi, öğretmen davranışlarının anlaşılması için oldukça önemli bir değişkendir (Enochs ve Riggs, 1990). Ancak bu araştırmada eğitime inanma, eğitim inançlarından ayrılan bir kavram olarak düşünülmüştür.

Eğitime inanma kavramlaştırması, yabancılaşma kuramıyla bağlantılı olarak açılanabilir. Bilindiği gibi, bireyler çok büyük çaplı toplumsal yapılar içinde kendi yerini ve toplumsal üretime katkısını algılamakta güçlük yaşamaktadır. Seeman'ın (1959) belirttiği gibi, böylesi bir durumda birey kendi eylemlerinin sonuçlar üzerindeki etkisini kestirememektedir (s. 786). Toplumsal yaşamda olduğu gibi, örgütlerde de yabancılaşma önemli bir sorun olarak karşımıza çıkmaktadır. Aşırı uzmanlaşma ve bölümleşme, çalışanların yapılan işin bütünü ile bağlarının kopmasına, dolayısıyla eylemlerinin örgütsel çıktılara katkısını görememelerine neden olabilmektedir. $\mathrm{Bu}$ durumun eğitim örgütleri için de geçerli olacağı düşünülebilir. Branşlaşmanın başladığı ortaokul ve liselerde matematik dersine giren öğretmen, dersinin iyi bir vatandaş yetiştirmekle bağlantısını kurmakta zorlanabilir. Özellikle, son dönemlerde neredeyse tamamen üst öğrenime geçiş sınavlarını kazandırmayı odağa alan ve eğitimin başarısını bu çoktan seçmeli sınavların puanları üzerinden açıklayan Türk eğitim sisteminde, branş öğretmenlerinin sonul ürün olan yetişkin bireyin hayattaki başarısı üzerindeki bireysel etkilerini sorgulamaları beklenen bir durumdur. Bu çıkarımı destekler biçimde, araştırmalar (örn. Erjem, 
2005; Eryılmaz ve Burgaz, 2011; Şimşek, Balay ve Şimşek, 2012; Y1lmaz ve Sarpkaya, 2009) Türkiye'de öğretmenlerin belirli düzeyde yabancılaşma yaşadıklarını göstermektedir.

Seeman (1967), yabancılaşmaya ilişkin tartışmalarında, yaptıkları işle ilgili karar süreçlerine katılamayan çalışanların kendilerini işlerinin sosyal ve kişisel çıktılarını etkilemek konusunda güçsüz hissedeceklerini belirtmektedir (s. 274). Erikson (1986) da çalışanların özgün bireysel katkılarını işlerine yansıtamamalarının yabancılaşmaya neden olduğunu dile getirmektedir (s. 1). Türkiye'de öğretmenler yaptıkları işle ilgili karar süreçlerine çok az dahil edilmektedir. Ders programlarının oluşturulmasından, kazanımların belirlenmesine, ölçme ve değerlendirme yöntemlerinden eğitim-öğretimin süresine kadar eğitim-öğretim süreçlerine ilişkin birçok değişken merkezden planlanmaktadır. Merkezin devrettiği kısıtlı yetki taşra yönetimlerince kullanılmakta, buradan artan eser miktardaki seçim şansı da okul yönetimlerince değerlendirilmektedir. $\mathrm{Bu}$ durumda öğretmenler, işlerinin aktif planlayıcıları yerine pasif uygulayıcıları konumuna düşmektedirler. Bu konumdaki öğretmen, öğrencinin çok yönlü gelişimini sağlamak konusunda kendisini güçsüz ve sisteme yabancılaşmış hissedebilecektir. $\mathrm{Bu}$ öğretmenler, bir yönüyle eğitim sistemine, kısaca eğitime olan inançlarını kaybetmektedirler. Eğitime inanma ile yabancılaşma bu yönüyle ilişkili kavramlar olmakla birlikte, eğitime inanmama durumu daha çok yabancılaşmanın bir sonucu olarak görülebilir.

Bir örgütün amaçları o örgütün varlık nedenidir (Aydın, 2005). Amaçlar, örgütlerin eyleme dönük yönünü ifade ettiği gibi çıktıları konusunda da fikir vermektedir. Eğitim örgütlerinin kurulmasının nedeni de eğitime ilişkin amaçları gerçekleştirmektir. Bu yönüyle, eğitimin amaçları, eğitim örgütlerinin işleyişi ve ürünleri hakkında önemli bilgiler sunmaktadır. Eğitimin amaçlarının gerçekleştiğine inanmak, eğitim sürecinin işleyişinin ve bu süreç sonunda ortaya çıkan ürünlerin hedeflenen nitelikte olduğuna inanmak anlamına gelmektedir. $\mathrm{Bu}$ noktadan hareketle, bu çalışmada eğitime inanma, eğitim örgütlerinin belirlenen amaçlara ulaşma durumuna inanma olarak kavramlaştırılmıştır. Diğer bir anlatımla, eğitimde belirlenen amaçlara ulaşıldığına inanan öğretmenin eğitim sistemine, kısaca eğitime inandığı kabul edilmiştir.

Eğitimin insanlığın tarihsel süreçteki yolculuğu kadar uzun bir zaman diliminde belirlenmiş birçok amacı bulunmaktadır. Türk eğitim sisteminin amaçları genel hatlarıyla 1739 sayılı Milli Eğitim Temel Kanunu'nda ifadesini bulmakla birlikte, bunun dışında birçok hukuksal metinde eğitim siteminin amaçlarına ilişsin belirleyici ifadeler yer almaktadır. Öğretim kademelerine yönelik özel amaçlar bunlar arasındadır. Bunun yanında hukuksal metinlere yansımayan yerel ve evrensel değerler, bilgi ve iletişimdeki hızlı ilerlemenin getirdiği yenileşme ve buna bağlı yeni sorumluluklar, eğitim sistemimize birçok yeni ve farklı amacı entegre etmiş ve etmektedir. Öğretmenlerin, okullarda yürütülen eğitim sürecinde tüm bu amaçlara ulaşıldığına inanmaları, onların yaptıkları işin doğrudan öğrenci gelişimiyle bağlantısını kurabilmelerine katkı sağlayacaktır. Yapılan işle ürün arasında kurulan böylesi bir bağlantı, öğretmenlerin harekete geçmelerine, özveride bulunmalarına, işlerini benimsemelerine ve mesleki gelişimlerine katkıda bulunacaktır. Bu açıdan, öğretmenlerin eğitimin amaçlarına inanma düzeylerinin düşüklüğü, eğitim örgütlerinin etkililiği açısından önemli bir sorun olarak görülebilir.

Türk eğitim sisteminde belirlenen amaçlara ne düzeyde ulaşıldığ konusunda kesin bir yargıya varmak zor olsa da, hem araştırmacıların hem de öğretmenlerin bu konuda çeşitli olumsuz algılarının olabileceği, uygulamadaki birçok olumsuzluk üzerinden ileri sürülebilir. Örneğin, 1739 sayılı Milli Eğitim Temel Kanunu'nda ifadesini bulan, vatanını, milletini seven, Türkiye Cumhuriyeti'ne karşı görev ve sorumluluklarını yerine getiren iyi bir vatandaş yetiştirme amacının ne ölçüde gerçekleştiği tartışmaya açıktır. Çocuk, eğer yıllar boyunca okula devam etiği halde, bir yetişkin olduğunda hala sıraya girme alışkanlığı kazanmamışsa, trafik kurallarına uymuyorsa ya da vergi kaçırmanın yollarını arıyorsa, iyi bir vatandaş yetiştirme konusunda sorunlar olduğu düşünülmelidir. Yine aynı genel amaçların ikinci bendinde, fiziksel, ahlaksal, ruhsal ve duygusal yönlerden gelişmiş bireyler yetiştirmenin hedeflendiği ifade edilmektedir. Oysa sistemden yetişenlere bakıldığında; spor yapma alışkanlığı ve hobileri olmayan, çeşitli ruhsal bunalımlar yaşayanların hiç de azımsanamayacak düzeyde olduğunu 
görmek zor değildir. Son olarak, eğitim sürecini tamamlayan bireylerin hem kendilerini mutlu k1lacak hem de toplumun mutluğuna katkıda bulunacak birer meslek sahibi olmaları amacına ulaşma konusundaki olumsuz örnekler de sistemin sorgulanmasını gerektirmektedir. Öğrenciler genellikle, kendilerini mutlu k1labilecek bir meslek yerine ailelerinin, toplumun, devletin, ekonominin, egemenlerin ve benzerlerinin isteklerine uygun mesleklere yönelmek zorunda kalmaktadır. Bu örnekleri en iyi gözlemleyebilenlerden biri de öğretmenlerdir. Bu gözlemlerin öğretmenlerin eğitime inanma durumlarını olumsuz etkileyeceği düşünülebilir.

Türk eğitim sisteminin temel amaçlarıyla birlikte temel ilkeleri de uygulama bakımından sorgulamaya açıktır. Örneğin genellik ve eşitlik ilkesine göre, eğitim kurumları hiçbir ayrım gözetmeksizin herkese açık olmalıdır. Oysa adrese dayalı kayıt sistemi uygulaması, kenar mahallelerde yaşayan çocukların merkezdeki okullara kayıt yaptırmasının önünde engel oluşturmaktadır. Kiraz'ın (2014) araştırma sonuçlarının da gösterdiği gibi, bu mahallelerde yaşayan ve bu okullara gitmek zorunda kalan çocukların sosyoekonomik bakımdan dezavantajlı bir sosyal sınıfi temsil ettikleri bilinmektedir (s. 72). Fırsat ve imkân eşitliği ilkesine göre, herkese eşit fırsatlar ve olanaklar sağlanmalıdır. Oysa her öğrenci özel okulda okuma firsatına sahip değildir. Devlet okulu da olsa, örneğin köy ve kent okullarında öğrencilere sunulan olanaklar da eşitlik anlayışına uygun görünmemektedir.

Dünyanın dördüncü sanayi devrimini tartıştığı bir dönemde bilimsel ve teknolojik gelişmelerin eğitimin amaçlarını etkilemeyeceği düşünülemez. Artık çocuklardan teknolojiyi kullanabilmenin yanında üretebilen bireyler olmaları beklenmektedir. Eski Amerika Birleşik Devletleri Başkanı Obama'nın söylediği gibi, çocuklardan bilgisayar oyunu oynarken yazmayı da düşünmeleri istenmektedir. Artık çağımızda bilginin sınırsız bir şekilde önümüze serilmesi bir yandan avantaj oluştururken bir yandan da önemli bir problemi beraberinde getirmektedir. Öğrencilere, bu sınırsız bilgi içinden işe yarar olanın nasıl süzülüp ilgilenilen sorunun çözümü için rafine edileceğine ilişkin beceriler kazandırılmak zorundadır. Türk eğitim sisteminin, herhangi bir hukuksal metinde yazsın ya da yazmasın, insan hakları ve demokrasi eğitimi, değerler eğitimi, barış eğitimi, çevre eğitimi gibi başka birçok alanda çeşitli amaçlarının olduğu ya da olması gerektiği ileri sürülebilir. Tüm bu konularda eğitim sisteminin amaçlara ulaşması noktasında tüm dünyada olduğu ya da olabileceği gibi Türkiye'de de çeşitli sorunlar yaşandığ göze çarpmaktadır. Bununla birlikte, bu gözlem ve çıkarımların bilimsel araştırmalarla desteklenmesi, konu edilen sorunların çözülebilmesine katkı sağlayacaktır.

$\mathrm{Bu}$ araştırmanın amacı, öğretmenlerin eğitimin amaçlarına ulaşma durumuna ilişkin inanma düzeylerini tespit etmek ve eğitime inanma durumlarını farklılaştırabileceği düşünülen çeşitli değişkenler açısından incelemektir. Bu doğrultuda şu sorulara yanıt aranmıştır.

1. Ögretmenler eğitimin belirlenen amaçlara ulaştığına ne düzeyde inanmaktadır?

2. Öğretmenlerin eğitimin belirlenen amaçlara ulaşma durumuna ilişkin inanma düzeyleri bağımsız değişkenlere (okul kademesi, kıdem, eğitim durumu, yöneticilik yapmış olma, karamsar / iyimser olma) göre farklılaşmakta mıdır?

\section{Yöntem}

Araştırmada nicel yöntem benimsenmiş olup, çalışma tarama modeline uygun biçimde desenlenmiştir. Tarama araştırmalarında belirli bir değişkene ilişkin var olan durumun betimlenmesi amaçlanmaktadır. $\mathrm{Bu}$ araştırmada da öğretmenlerin eğitimin belirlenen amaçlara ulaşma durumuna ilişkin var olan inançları kendi algılarına dayalı olarak belirlenmiş̧tir.

\section{Çalışma grubu}

Araştırma verileri Tokat'ta kamu ilköğretim ve ortaöğretim okullarında görev yapan öğretmenlerden toplanmıştır. Araştırmaya belirtilen okullarda görev yapan ve gönüllü olan 546 öğretmen katılmıştır. Katılımcılar basit seçkisiz örnekleme tekniği ile belirlenmiştir (Büyüköztürk, Çakmak, Akgün, Karadeniz ve Demirel, 2012, 85-86). Katılımcıların 247'si ilköğretim (114 ilkokul + 133 ortaokul), 299'u ortaöğretim okullarında görev yapmaktadır. Öğretmenlerden 169'unun kıdemi 1-10 yıl, 123'ünün kıdemi 11-15 yıl, 123'ünün kıdemi 16-20 yıl arasında ve 131'inin kıdemi ise 21 yıl ve üzerindedir. Araştırmaya katılan öğretmenlerden 
56's1 ön lisans, 423'ü lisans ve 67'si lisansüstü eğitim mezunudur. Katılımc1lardan 94'ü sınıf öğretmeni, 46's1 sosyal alanlar öğretmeni (sosyal bilgiler, tarih, coğrafya vb.), 132'si fen ve matematik alanları öğretmeni (fen ve teknoloji, matematik, fizik vb.), 113'ü dil ve edebiyat öğretmeni (Türkçe, Türk dili, İngilizce, Arapça vb.), 46's1 din kültürü ve felsefe öğretmeni, 48'i beceri dersleri öğretmeni (beden eğitimi, resim, müzik vb.) ve 67'si ise diğer alanlardaki (rehberlik, çocuk gelişimi vb.) öğretmenlerdir. Katılımcılardan 175 'inin yöneticilik deneyimi bulunmaktadır. Öğretmenlerden 52'si kendisini genel anlamda daha çok karamsar olarak nitelendirmektedir.

\section{Veri toplama araci}

Araştırma verileri, kişisel bilgi formu ve Akın ve Yıldırım (2015) tarafından geliştirilen Öğretmenlerin Eğitime İnanma Düzeyleri Ölçeği (ÖEİDÖ) aracılığıyla toplanmıştır. ÖEİDÖ 25 maddeden oluşmaktadır. Ölçek toplumsallaştırma, bireysel farklılıklar, çok yönlü gelişim ve üst öğrenime hazırlama olmak üzere dört alt boyuttan oluşmaktadır. Dört boyutun açıkladığı toplam varyans \% 65.9 olarak rapor edilmiştir. Her bir maddede öğretmenlerin eğitimin ilgili boyutta yer alan bir amacına ne derecede ulaştığına inandıkları puanlanmaktadır. Örneğin "öğrencilerin sosyal yönden geliştirildiğine inanıyorum" ifadesi ölçeğin çok yönlü gelişim boyutunda yer almaktadır. Öğretmenlerden ölçek maddelerini hiç katılmıyorum (1) ve tamamen katılıyorum (5) aralığında puanlamaları istenmektedir. Ölçekten alınan 1.00 ile 5.00 arasındaki puanlar şu biçimde değerlendirilmiştir: 1.00-1.79= hiç katılmıyorum, 1.80-2.59= çok az katılıyorum, 2.60$3.39=$ orta düzeyde kat1lıyorum, 3.40-4.19= büyük ölçüde katılıyorum ve 4.20-5.00= tamamen katılıyorum. Ölçek geliştirme çalışmasında Cronbach alpha iç tutarlık katsayıları toplumsallaştırma boyutu için .94, çok yönlü gelişim boyutu için .88 , bireysel farkl1lıklar boyutu için .87 ve üst öğrenime hazırlama boyutu için .69 olarak tespit edilmiştir. Bu çalışma için hesaplanan değerler sirasıyla $.95, .87, .85$ ve .70 'tir.

\section{İşlem}

Araştırma verileri 2015-2016 eğitim-öğretim yılı güz yarıyılında Tokat’taki kamu ilköğretim ve ortaöğretim okullarında görev yapan öğretmenlerden toplanmıştır. Veriler araştırmacılar tarafından okulların ziyaret edilmesi ve araştırmaya katılmaya gönüllü olan öğretmenlere ölçme araçlarının uygulanması yoluyla elde edilmiştir.

\section{Verilerin analizi}

Öğretmenlerin eğitime inanma düzeylerini betimlenmek üzere ortalama ve standart sapma değerleri hesaplanmıştır. Öğretmenlerin eğitime inanma düzeylerinin okul kademesi, kıdem ve eğitim durumuna göre farklılaşma durumunu incelemek üzere ANOVA testi yapılmıştır. Katılımcıların eğitime inanma düzeylerinin yöneticilik yapmış olma ve karamsar ya da iyimser olma durumlarına göre farklılaşıp farklılaşmadığ

\section{Bulgular}

\section{Ö̆rretmenlerin eğitime inanma düzeyleri}

Araştırma kapsamında yanıt aranan ilk soru öğretmenlerin eğitimin belirlenen amaçlara ne ölçüde ulaştığına ilişkin inanma düzeylerini belirlemektir. Bu amaçla her bir maddenin ve ölçek alt boyutlarının ortalama ve standart sapma değerleri hesaplanmış, sonuçlar Tablo 1'de betimlenmiştir.

Tablo 1'de görüldüğü gibi, öğretmenler eğitimin toplumsallaştırma ile ilgili amaçlarına ulaşıldığına orta düzeyde inanmaktadır $(\bar{X}=2.69)$. Öğretmenler bu boyutta görece en çok, öğrencilere olumlu kişilik özellikleri kazandırıldığına $(\bar{X}=2.93)$ ve öğrencilerin devleti koruma bilincine sahip bireyler olarak yetiştirildiğine $(\bar{X}=2.91)$ inandıklarını belirtmişlerdir. Öte yandan öğretmenlerin görece en az, öğrencilerin her alanda üretken bireyler olarak yetiştirildiğine $(\bar{X}=2.43)$, öğrencilere bilimsel bakış açısı kazandırıldığına $(\bar{X}=2.52)$ ve 
öğrencilerin memleket sorunlarına duyarlı bireyler olarak yetiştirildiğine $(\bar{X}=2.53)$ inandıkları anlaşılmaktadır.

Tablo 1. Ögretmenlerin Ĕ̈itime İnanma Düzeyleri

\begin{tabular}{|c|c|c|c|}
\hline Değişken & Boyut & $\bar{X}$ & ss \\
\hline \multirow{12}{*}{$\begin{array}{l}\text { Toplumsallaştırma } \\
\qquad(\bar{X}=2.69)\end{array}$} & Öğrencilere etik değerlerin benimsetildiğine inanıyorum. & 2.83 & 0.98 \\
\hline & $\begin{array}{l}\text { Öğrencilerin memleket sorunlarına duyarlı bireyler olarak } \\
\text { yetiștirildiğine inanıyorum. }\end{array}$ & 2.53 & 1.06 \\
\hline & $\begin{array}{l}\text { Öğrencilerin topluma yararlı birer vatandaş olarak } \\
\text { yetiştirildiğine inanıorum. }\end{array}$ & 2.86 & 0.96 \\
\hline & $\begin{array}{l}\text { Öğrencilerin her alanda üretken bireyler olarak yetiştirildiğine } \\
\text { inanıyorum. }\end{array}$ & 2.43 & 0.88 \\
\hline & $\begin{array}{l}\text { Öğrencilerin bilinçli birer tüketici olarak yetiştirildiğini } \\
\text { düşünüyorum. }\end{array}$ & 2.55 & 1.01 \\
\hline & Öğrencilere çevre bilinci kazandıııldığına inanıyorum. & 2.80 & 0.97 \\
\hline & $\begin{array}{l}\text { Öğrencilerin ülke kalkınmasına katkıda bulunabilen bireyler } \\
\text { olarak yetiştirildiğine inanıyorum. }\end{array}$ & 2.69 & 0.93 \\
\hline & $\begin{array}{l}\text { Öğrencilerin öğrenmekten keyif alan bireyler olarak } \\
\text { yetiştirildiğine inanıyorum. }\end{array}$ & 2.55 & 1.03 \\
\hline & Öğrencilerin mutlu birer birey haline getirildiğine inanıyorum. & 2.71 & 0.98 \\
\hline & $\begin{array}{l}\text { Öğrencilere olumlu kişilik özellikleri kazandırıldığına } \\
\text { inanıyorum. }\end{array}$ & 2.93 & 0.92 \\
\hline & Öğrencilere bilimsel bakış açısı kazandırıldığına inanıyorum. & 2.52 & 1.01 \\
\hline & $\begin{array}{l}\text { Öğrencilerin devleti koruma bilincine sahip bireyler olarak } \\
\text { yetiştirildiğine inanıyorum. }\end{array}$ & 2.91 & 1.08 \\
\hline \multirow{5}{*}{$\begin{array}{l}\text { Bireysel Farklilıklar } \\
\qquad(\bar{X}=2.55)\end{array}$} & Öğrencilere firsat eşitliği sağlandığına inanıyorum. & 2.37 & 0.95 \\
\hline & $\begin{array}{l}\text { Öğrencilerin yeteneklerine uygun bir eğitim verildiğine } \\
\text { inanıyorum. }\end{array}$ & 2.44 & 0.96 \\
\hline & $\begin{array}{l}\text { Öğrencilerin becerilerine uygun ortamlar hazırlandığına } \\
\text { inanıyorum. }\end{array}$ & 2.51 & 1.00 \\
\hline & $\begin{array}{l}\text { Öğrencilerin bireysel farklılıklarının dikkate alındığına } \\
\text { inanıyorum. }\end{array}$ & 2.49 & 0.98 \\
\hline & Öğrencilerin gerçek hayata hazırlandığına inanıyorum. & 2.95 & 1.11 \\
\hline \multirow{5}{*}{$\begin{array}{l}\text { Çok Yönlü Gelişim } \\
\qquad(\bar{X}=2.91)\end{array}$} & $\begin{array}{l}\text { Öğrencilere Türkçeyi düzgün kullanma becerisi } \\
\text { kazandırıldığına inanıyorum. }\end{array}$ & 2.86 & 1.02 \\
\hline & $\begin{array}{l}\text { Öğrencilerin ruhsal yönden sağlıklı birer birey olarak } \\
\text { yetiştirildiğine inanıyorum. }\end{array}$ & 3.05 & 0.95 \\
\hline & $\begin{array}{l}\text { Öğrencilerin fiziksel yönden sağlıklı birer birey olarak } \\
\text { yetiştirildiğine inanıyorum. }\end{array}$ & 2.86 & 0.98 \\
\hline & Öğrencilerin sosyal yönden geliştirildiğine inanıyorum. & 2.88 & 1.02 \\
\hline & $\begin{array}{l}\text { Öğrencilere milli ve manevi değerlerin kazandırıldığına } \\
\text { inanıyorum. }\end{array}$ & 2.91 & 0.95 \\
\hline \multirow{3}{*}{$\begin{array}{l}\text { Üst Öğrenime } \\
\text { Hazırlama } \\
(\bar{X}=2.94)\end{array}$} & $\begin{array}{l}\text { Öğrencilerin her alanda okuryazar bireyler olarak } \\
\text { yetiştirildiğine inaniyorum. }\end{array}$ & 2.78 & 0.97 \\
\hline & $\begin{array}{l}\text { Ögrencilerin bilgi ve iletişim teknolojileri konusunda donanımlı } \\
\text { olarak yetiştirildiğine inanıorum. }\end{array}$ & 2.83 & 1.04 \\
\hline & $\begin{array}{l}\text { Öğrencilerin üst öğrenime en iyi biçimde hazırlandığına } \\
\text { inanıyorum. }\end{array}$ & 3.21 & 0.98 \\
\hline
\end{tabular}

Öğretmenler bireysel farklılıklar boyutunda yer alan amaçlara ulaşıldığına çok az inanmaktadırlar $(\bar{X}=2.55)$. Katılımcılar bu boyutta görece en çok öğrencilerin gerçek hayata hazırlandıklarına inandıklarını belirtirken $(\bar{X}=2.95)$, görece en az öğrencilere fırsat eşitliği sağlandığına inandıklarını belirtmişlerdir $(\bar{X}=2.37)$.

Katılımcılar eğitimin çok yönlü gelişim boyutundaki amaçlarına orta düzeyde ulaşıldığına inanmaktadır ( $\bar{X}=2.91)$. Öğretmenler bu boyutta görece en çok öğrencilerin ruhsal 
yönden sağlıklı birer birey olarak yetiştirildiğine inandıkları görülmektedir $(\bar{X}=3.05)$. Diğer taraftan katılımcılar, görece en az öğrencilere Türkçeyi düzgün kullanma becerisi kazandırıldığına $(\bar{X}=2.86)$ ve öğrencilerin fiziksel yönden sağlıklı bireyler olarak yetiştirildiğine inandıkları anlaşılmaktadır $(\bar{X}=2.86)$.

Tablo 1'de görüldüğü üzere, katılımc1lar eğitimin üst öğrenime hazırlama boyutundaki amaçlarına orta düzeyde inanmaktadır $(\bar{X}=2.94)$. Bu boyutta öğretmenler görece en çok, öğrencilerin üst öğrenime en iyi biçimde hazırlandığına inanırken $(\bar{X}=3.21)$, görece en az her alanda okur-yazar bireyler olarak yetiştirildiğine inanmaktadır $(\bar{X}=2.78)$.

\section{Öğretmenlerin eğitime inanma düzeylerinin çeşitli değişkenlere göre incelenmesi}

Araştırma kapsamında yanıt aranan ikinci soru öğretmenlerin eğitime inanma düzeylerinin okul kademesi, kıdem, eğitim durumu, yöneticilik yapmış olma ve karamsar ya da iyimser olma durumlarına göre farklılaşıp farklılaşmadığıdır. Öğretmenlerin eğitime inanma düzeylerinin okul kademesine göre farklılaşma durumunu incelemek üzere ANOVA testi yapılmış, sonuçlar Tablo 2'de sunulmuştur.

Tablo 2. Okul Kademesine Göre Farklılaşma

\begin{tabular}{|c|c|c|c|c|c|c|c|c|}
\hline & & $\begin{array}{l}\text { Okul } \\
\text { Kademesi }\end{array}$ & $N$ & $\bar{X}$ & $s d$ & $F$ & $p$ & Anlamlı Fark \\
\hline \multirow{12}{*}{$\begin{array}{l}\text { Eğitime } \\
\text { İnanma }\end{array}$} & \multirow{3}{*}{ Toplumsallaştırma } & İlkokul & 114 & 2.99 & & \multirow{3}{*}{12.171} & \multirow{3}{*}{$.000 *$} & \multirow{3}{*}{$\begin{array}{c}\text { İlkokul/Ortaokul- } \\
\text { Lise }\end{array}$} \\
\hline & & Ortaokul & 133 & 2.72 & & & & \\
\hline & & Lise & 299 & 2.57 & & & & \\
\hline & \multirow{3}{*}{$\begin{array}{l}\text { Bireysel } \\
\text { Farkl111klar }\end{array}$} & İlkokul & 114 & 2.72 & & \multirow{3}{*}{3.557} & \multirow{3}{*}{$.029 *$} & \multirow{3}{*}{ İlkokul/Lise } \\
\hline & & Ortaokul & 133 & 2.52 & & & & \\
\hline & & Lise & 299 & 2.49 & & & & \\
\hline & \multirow{3}{*}{$\begin{array}{l}\text { Çok Yönlü } \\
\text { Gelişim }\end{array}$} & İlkokul & 114 & 3.18 & $2-543$ & \multirow{3}{*}{11.143} & \multirow{3}{*}{$.000 *$} & \multirow{3}{*}{ İlkokul/Lise } \\
\hline & & Ortaokul & 133 & 2.95 & & & & \\
\hline & & Lise & 299 & 2.79 & & & & \\
\hline & \multirow{3}{*}{$\begin{array}{l}\text { Üst Öğrenime } \\
\text { Hazırlama }\end{array}$} & İlkokul & 114 & 3.20 & & \multirow{3}{*}{8.310} & \multirow{3}{*}{$.000^{*}$} & \multirow{3}{*}{$\begin{array}{c}\text { İlkokul/Ortaokul- } \\
\text { Lise }\end{array}$} \\
\hline & & Ortaokul & 133 & 2.93 & & & & \\
\hline & & Lise & 299 & 2.85 & & & & \\
\hline
\end{tabular}

$* p<.05$

Tablo 2'de görüldüğü gibi, öğretmenlerin eğitime inanma düzeyleri çalıştıkları okul kademesine göre tüm boyutlarda anlamlı biçimde farklılaşmaktadır $(p<.05)$. Farklılığın kaynağını bulmak üzere yapılan çoklu karşılaştırma testi sonuçlarına göre, toplumsallaştırma ve üst öğrenime hazırlama boyutlarında ilkokul öğretmenleri, eğitimin amaçlarına ulaştığına hem ortaokul hem de lise öğretmenlerine göre anlamlı biçimde daha fazla inanmaktadır. Bireysel farklılıklar ve çok yönlü gelişim boyutlarında ise ilkokul öğretmenlerinin lise öğretmenlerine göre amaçlara ulaşıldığına daha fazla inandıkları anlaşılmaktadır.

Katılımcıların kıdemlerinin eğitimin amaçlarına ulaşmasına inanma düzeylerini farklılaştırma durumunu test etmek üzere ANOVA testi yapılmış, analiz sonuçları Tablo 3 'te sunulmuştur.

Tablo 3'ten de izlenebileceği üzere, katılımcıların eğitime inanma düzeyleri toplumsallaştırma ve bireysel farklılıklar boyutlarında kıdemlerine göre fark göstermemektedir. Bununla birlikte, çok yönlü gelişim ve üst öğrenime hazırlama boyutlarında öğretmenlerin kıdemlerine göre anlamlı farklılık tespit edilmiştir. Çoklu karşılaştırma testi sonuçlarına göre, üst öğrenime hazırlama boyutunda 20 yıldan çok kıdemi olan öğretmenler eğitimin amaçlarına ulaştığına hem 11-15 yıl hem de 16-20 yıl kıdemi olanlardan daha fazla inanmaktadırlar. Üst öğrenime hazırlama boyutunda ise 20 yıldan fazla kıdemi olanlar eğitimin amaçlarına ulaştığına diğer öğretmenlerden daha fazla inanmaktadırlar. 
Tablo 3. Kıdeme Göre Farklılaşma

\begin{tabular}{|c|c|c|c|c|c|c|c|c|}
\hline & & Kidem & $N$ & $\overline{\bar{X}}$ & $s d$ & $F$ & $p$ & Anlamlı Fark \\
\hline \multirow{16}{*}{$\begin{array}{l}\text { Eğitime } \\
\text { İnanma }\end{array}$} & & $1-10 y_{11}$ & 169 & 2.71 & \multirow{16}{*}{$3-542$} & \multirow{4}{*}{1.345} & \multirow{4}{*}{.259} & \multirow{4}{*}{ - } \\
\hline & & $11-15$ y1l & 123 & 2.60 & & & & \\
\hline & Toplumsallaştırma & $16-20$ y1l & 123 & 2.65 & & & & \\
\hline & & $>20$ y1l & 131 & 2.79 & & & & \\
\hline & & $1-10$ y1l & 169 & 2.59 & & \multirow{4}{*}{1.452} & \multirow{4}{*}{.227} & \multirow{4}{*}{ - } \\
\hline & Bireysel & $11-15$ y1l & 123 & 2.47 & & & & \\
\hline & Farkl1lıklar & $16-20 \mathrm{y}_{11}$ & 123 & 2.48 & & & & \\
\hline & & $>20$ y1l & 131 & 2.64 & & & & \\
\hline & & $1-10 \mathrm{y} 11$ & 169 & 3.00 & & \multirow{4}{*}{2.771} & \multirow{4}{*}{$.041 *$} & \multirow{4}{*}{$\begin{array}{c}>20 \mathrm{y} 11 / 11-15 \\
\text { y1l-16-20 y1l }\end{array}$} \\
\hline & Çok Yönlü & $11-15$ y11 & 123 & 2.80 & & & & \\
\hline & Gelişim & $16-20$ y1l & 123 & 2.82 & & & & \\
\hline & & $>20$ yıl & 131 & 3.00 & & & & \\
\hline & & $1-10$ y1l & 169 & 2.84 & & \multirow{4}{*}{4.863} & \multirow{4}{*}{$.002 *$} & \multirow{4}{*}{$\begin{array}{c}>20 \text { y1 } 1 / 1-10 \text { y1l- } \\
11-15 \text { y1l-16-20 } \\
\text { y1l }\end{array}$} \\
\hline & Üst Öğrenime & $11-15$ y1l & 123 & 2.85 & & & & \\
\hline & Hazırlama & $16-20$ y1l & 123 & 2.94 & & & & \\
\hline & & $>20$ yil & 131 & 3.16 & & & & \\
\hline
\end{tabular}
${ }^{*} p<.05$

Katılımcıların eğitime inanma düzeylerinin eğitim durumuna göre farklılaşma durumunu test etmek üzere ANOVA testi yapılmış, sonuçlar Tablo 4'te sunulmuştur.

Tablo 4. Ĕ̈itime Göre Farklılaşma

\begin{tabular}{|c|c|c|c|c|c|c|c|c|}
\hline & & $\begin{array}{l}\text { Eğitim } \\
\text { Durumu }\end{array}$ & $N$ & $\bar{X}$ & $s d$ & $F$ & $p$ & Anlamlı Fark \\
\hline \multirow{12}{*}{$\begin{array}{l}\text { Eğitime } \\
\text { İnanma }\end{array}$} & & Önlisans & 56 & 2.75 & \multirow{12}{*}{$2-543$} & \multirow{3}{*}{.916} & \multirow{3}{*}{.401} & \multirow{3}{*}{ - } \\
\hline & Toplumsallaştırma & Lisans & 423 & 2.70 & & & & \\
\hline & & Lisansüstü & 67 & 2.57 & & & & \\
\hline & & Önlisans & 56 & 2.64 & & \multirow{3}{*}{1.238} & \multirow{3}{*}{.291} & \multirow{3}{*}{ - } \\
\hline & Bireysel & Lisans & 423 & 2.56 & & & & \\
\hline & & Lisansüstü & 67 & 2.42 & & & & \\
\hline & & Önlisans & 56 & 3.03 & & \multirow{3}{*}{1.299} & \multirow{3}{*}{.274} & \multirow{3}{*}{-} \\
\hline & $\begin{array}{l}\text { ÇOK Y onlu } \\
\text { Selisim }\end{array}$ & Lisans & 423 & 2.91 & & & & \\
\hline & & Lisansüstü & 67 & 2.81 & & & & \\
\hline & & Önlisans & 56 & 3.06 & & \multirow{3}{*}{1.363} & \multirow{3}{*}{.257} & \multirow{3}{*}{ - } \\
\hline & $\begin{array}{l}\text { Ust Ogrenıme } \\
\text { Hazurlama }\end{array}$ & Lisans & 423 & 2.94 & & & & \\
\hline & & Lisansüstü & 67 & 2.83 & & & & \\
\hline
\end{tabular}

$* p<.05$

Tablo 4’te görüldüğ̈̈ gibi, öğretmenlerin eğitime inanma düzeyleri eğitim durumlarına göre hiçbir boyutta anlamlı biçimde farklılaşmaktadır $(p>.05)$.

Öğretmenlerin eğitime inanma düzeylerinin yöneticilik yapmış olma durumlarına göre fark gösterip göstermediğini belirlemek üzere t testi yapılmış, sonuçları Tablo 5 'te sunulmuştur.

Tablo 5. Yöneticilik Yapmış Olma Durumuna Göre Farklılaşma

\begin{tabular}{|c|c|c|c|c|c|c|c|}
\hline & & $\begin{array}{l}\text { Yöneticilik } \\
\text { Deneyimi }\end{array}$ & $N$ & $\bar{X}$ & $s d$ & $t$ & $p$ \\
\hline \multirow{4}{*}{$\begin{array}{l}\text { Eğitime } \\
\text { İnanma }\end{array}$} & Toplumsallaştırma & $\begin{array}{l}\text { Evet } \\
\text { Hayır }\end{array}$ & $\begin{array}{l}175 \\
371\end{array}$ & $\begin{array}{l}2.74 \\
2.67\end{array}$ & \multirow{4}{*}{544} & 1.019 & .308 \\
\hline & Bireysel Farkl11ıklar & $\begin{array}{l}\text { Evet } \\
\text { Hayir }\end{array}$ & $\begin{array}{l}175 \\
371\end{array}$ & $\begin{array}{l}2.66 \\
2.50\end{array}$ & & 2.150 & $.032 *$ \\
\hline & Çok Yönlü Gelişim & $\begin{array}{l}\text { Evet } \\
\text { Hayır }\end{array}$ & $\begin{array}{l}175 \\
371\end{array}$ & $\begin{array}{l}3.00 \\
2.87\end{array}$ & & 1.751 & .081 \\
\hline & Üst Öğrenime Hazırlama & $\begin{array}{l}\text { Evet } \\
\text { Hayır }\end{array}$ & $\begin{array}{l}175 \\
371\end{array}$ & $\begin{array}{l}3.04 \\
2.89\end{array}$ & & 2.060 & $.040^{*}$ \\
\hline
\end{tabular}

${ }^{*} p<.05$ 
Tablo 5'te görüldüğ̈̈ üzere, katılımcıların eğitime inanma düzeyleri toplumsallaştırma ve çok yönlü gelişim düzeylerinde yöneticilik yapmış olma durumlarına göre farklılaşmamaktadır ( $\mathrm{p}>.05$ ). Öte yandan yöneticilik deneyimi bulunan katılımcılar hem bireysel farklılıklar hem de üst öğrenime hazırlama boyutlarında eğitimin amaçlarına ulaştığına anlamlı biçimde daha fazla inanmaktadırlar.

Öğretmenlerin eğitime inanma düzeylerinin kendilerini karamsar ya da iyimser olarak tanımlamalarına göre farklılaşma durumunu incelemek üzere t testi yapılmış, sonuçlar Tablo 6'da sunulmuştur.

Tablo 6. Karamsar ya da İimser Olma Durumuna Göre Farklllaşma

\begin{tabular}{|c|c|c|c|c|c|c|c|}
\hline & & $\begin{array}{l}\text { Karamsar / } \\
\text { İyimser }\end{array}$ & $N$ & $\bar{X}$ & $s d$ & $t$ & $p$ \\
\hline \multirow{4}{*}{$\begin{array}{l}\text { Eğitime } \\
\text { İnanma }\end{array}$} & Toplumsallaştırma & $\begin{array}{l}\text { Karamsar } \\
\text { İyimser }\end{array}$ & $\begin{array}{c}52 \\
494 \\
\end{array}$ & $\begin{array}{l}2.29 \\
2.73 \\
\end{array}$ & \multirow{4}{*}{544} & -3.864 & $.000^{*}$ \\
\hline & Bireysel Farklılıklar & $\begin{array}{l}\text { Karamsar } \\
\text { İyimser }\end{array}$ & $\begin{array}{c}52 \\
494 \\
\end{array}$ & $\begin{array}{l}2.19 \\
2.59\end{array}$ & & -3.412 & $.001 *$ \\
\hline & Çok Yönlü Gelişim & $\begin{array}{l}\text { Karamsar } \\
\text { İyimser }\end{array}$ & $\begin{array}{c}52 \\
494\end{array}$ & $\begin{array}{l}2.51 \\
2.95\end{array}$ & & -3.966 & $.000^{*}$ \\
\hline & Üst Öğrenime Hazırlama & $\begin{array}{l}\text { Karamsar } \\
\text { İyimser }\end{array}$ & $\begin{array}{c}52 \\
494\end{array}$ & $\begin{array}{l}2.69 \\
2.97\end{array}$ & & -2.415 & $.016^{*}$ \\
\hline
\end{tabular}

${ }^{*} p<.05$

Tablo 6'dan da izlenebileceği üzere, katılımcıların eğitime inanma düzeyleri tüm boyutlarda kendilerini karamsar ya da iyimser olarak tanımlamalarına göre anlamlı biçimde farklılaşmaktadır $(\mathrm{p}<.05)$. Ortalamalar dikkate alındığında, kendisini daha çok iyimser olarak tanımlayanların karamsar olarak tanımlayanlara göre eğitime daha fazla inandıkları anlaşılmaktadır.

\section{Tartışma, Sonuç ve Öneriler}

Öğretmenler eğitimin toplumsallaştırma, çok yönlü gelişim ve üst öğrenime hazırlama ile ilgili amaçlarına ulaşıldığına orta düzeyde inanırken, bireysel farklılıklara ilişkin amaçlara ulaşıldığına çok az inanmaktadır. Tüm boyutlar birlikte değerlendirildiğinde öğretmenlerin en çok öğrencilerin üst öğrenime en iyi biçimde hazırlandığına inandıkları görülmektedir. Türk eğitim sistemi, büyük ölçüde üst öğrenime geçiş için yapılan sinavlara odaklı bir görüntü sergilemektedir. 2007-2013 arasını kapsayan Dokuzuncu Kalkınma Planı'nda, sınav odaklı eğitim sisteminin birçok olumsuzluğu beraberinde getirdiği, eğitimin amaçlarına ulaşmasını zorlaştırdığı ve bu durumun düzeltilmesinin planlandığı belirtilmektedir (Devlet Planlama Teşkilatı [DPT], 2006). Ancak, dershanelerin kapatılmasına rağmen, sınava hazırlık amaçlı takviye kurslarının okullar bünyesinde devam etmesi, sistemin sinav odaklılıktan uzaklaşamadığını göstermektedir. Çokça eleştirilmesine karşın, halen okulların ve eğitim sisteminin etkililiği değerlendirilirken çoğu durumda ortaöğretime ve yüksek öğretime geçiş sınavlarındaki başarı ölçüt alınmaktadır. Bu durumun rasyonel bir sonucu olarak, okul yöneticileri ve öğretmenler sınav başarısına odaklanmaktadır. Böyle bir ortamda, öğretmenlerin öğrencilerin üst öğrenime hazırlanması konusunda daha yüksek puanlar verdikleri düşünülebilir.

Öğrencileri üst öğrenime hazırlamak eğitim sistemlerinin önemli amaçlarından biridir. Ancak var olan durumdaki yaklaşımla, bu hazırlığı sınav odaklı bir anlayışla yapmanın önemli sakıncaları olduğunu vurgulamakta yarar vardır. Öncelikle böylesi bir anlayış, yapıcı olmayan, yarışmaya dayalı bir rekabet ortamı oluşturmaktadır. Öğrenciler, öğretmenler, yöneticiler ve veliler bu sistemin gerekliliklerini yerine getirmek için yoğun çaba göstermekte, ancak yarışma anlayışının gereği olarak çok az öğrenci başarıyı tadabilmektedir. Bunun yanında öğretmenler, sınavı öncelemekte, programın öğrencinin sosyalleştirilmesi, çeşitli değerlerin kazandırılması gibi eğitim kazanımları görmezden gelinmektedir. Bunun da ötesinde, üst öğrenime hazırlamak, öğrenciye bir sonraki öğretim kademsinde gereksinim duyacağı bilgi, beceri ve davranışları kazandırmak anlamına gelmektedir. Oysa var olan çoktan seçmeli sınavların bu anlayıştan uzak 
olduğu görülmektedir. Milli Eğitim Bakanlığı bu durumu tersine çevirmek için çeşitli önlemler alabilir. Ortaöğretim kurumlarına öğrenci yerleştirilirken sınav puanına göre sıralama yapılmayıp öğrencilere liseler arasında tercih yapma şansı verilebilir. Ancak bunun için öncelikle liseler arasındaki nitelik farklılıklarını gidermeye yönelik adımlar atılmalıdır. Çünkü var olan durumda ortaöğretim kurumları yarışma sınavı yapılmasını gerekli ve haklı kılacak biçimde birbirinden farklı durumlarda bulunmaktadır. Yükseköğretime geçişte ise öğrencinin geçmiş öğrenim yaşantısı ve buradaki performansının daha çok dikkate alınması gerekmektedir. Ancak, böylesi bir uygulama, daha okula kayıt yaptırırken öğrencilere yüksek notlar verileceğini vadeden bir yaklaşımla olanaklı görünmemektir. 12 yıl zorunlu eğitime devam eden öğrenciler için en başından sıkı, düzenli ve nesnel biçimde tutulacak kayıtlar ve yapılacak değerlendirme sonuçları üniversiteye girişte dikkate alınabilir.

Araştırma sonuçlarına göre, öğretmenlerin gerçekleştiğine en az inandıkları amaç öğrencilere firsat eşitliği sağlanması ile ilgili olandır. Eğitimde fırsat eşitliği, tüm çocuklara eğitim hizmetlerinden yararlanma konusunda eşit fırsatlar sunulmasını ifade eden bir kavramdır. Türkiye'de tüm çocuklara eşit eğitim firsatları sunulması ilke olarak kabul edilmiş olsa da, özellikle köylerde, kenar mahallelerde ve benzer dezavantajlı bölgelerde yaşayan yoksul ailelerin çocuklarının eğitim firsatlarından zengin aile çocuklarıyla eşit biçimde yararlandığ tartışmaya açıktır (bkz. Akın, 2015, s. 13-14). Eğitim sisteminin bu önemli sorunu araştırma sonuçlarında da tespit edilmiş olmaktadır. Bu sorunun çözümü, dünyada ve Türkiye'de yükselen trendin aksine, devletin eğitimin finansmanında daha fazla sorumluluk üstlenmesiyle olanaklı hale gelebilecektir. Var olan durumda yoksul olan öğrencilerden başarılı olanlar çeşitli burslarla desteklenmektedir. Bu destekler arttırılabilir. Ancak yoksul olup yüksek başarı gösteremeyen çocukları, benzer akademik performansa sahip sosyoekonomik düzeyi yüksek çocuklarla eğitim firsatları açısından eşitlemek üzere de çalışmalar yapılmalıdır.

Araştırmada öne çıkan başka bir sonuç, ilkokul öğretmenlerinin eğitimin belirlenen amaçlara ulaştığına ortaokul ve lise öğretmenlerine göre daha fazla inanmasıdır. Bu sonuç, ilkokul öğretmenlerinin öğrencilerle daha uzun süre birlikte olmasından ve öğrencilerin gelişim sürecini gözlemleyebilme firsatı bulmalarından kaynaklanıyor olabilir. Ortaokul ve lise öğretmenleri öğrencilerin yalnızca bir ya da bazı durumlarda birkaç dersine girmekte, eğitim sürecinin küçük bir parçasını gözlemleyebilmektedir. Örgütlerde üretim sürecinde aşırı uzmanlaşmaya dayalı işbölümünün sonuçlarından biri de işe yabancılaşma olarak karşımıza çıkmaktadır. Ortaokul ve lise öğretmenleri de ilkokul öğretmenlerine göre daha fazla yabancılaşma yaşıyor olabilir. Bu çıkarımı destekler biçimde Erjem (2005), Türkiye'de lise eğitiminin görece daha sorunlu olduğunu, olumsuz şartlarda yapıldığını ve dolayısıyla bu kademedeki öğretmenlerin daha yoğun yabancılaşma yaşayabileceklerini belirtmektedir. Yılmaz ve Sarpkaya (2009) da sınıf öğretmenlerinin branş öğretmenlerinden daha az yabancılaşma yaşadıklarını bildirmektedir (s. 324). Banai ve Reisel'e (2007) göre yabancılaşmanın önemli sonuçlarından biri de örgütün amaçlarıyla ilgilidir. Seeman'ın (1959) belirttiği gibi, yabancılaşma yaşayan birey yaptıklarının sonuca etkisinin olmayacağını düşünmekte, dolayısıyla yaptığı iş ile örgütün amaçları arasındaki bağlantıyı kurmakta zorlanmaktadır. Benzer biçimde ortaokul ve lise öğretmenleri de verdikleri derslerle eğitim sisteminin amaçları arasındaki bağlantıyı kurmakta zorlanıyor, dolayısıyla da eğitime görece daha az inanıyor olabilir. Ortaokul ve lise öğretmenlerinin eğitime daha fazla inanmalarının sağlanması için onların bir eğitimci olarak yabancılaşmalarını önlemek bir öneri olarak sunulabilir. Bunun için ortaokuldaki bir matematik ya da lisedeki bir fizik öğretmeninin, bir öğretmen olarak sorumluluğunun öğrencilere yalnızca matematik ve fizik öğretmek olmadığının farkına varması gerekmektedir. Bir matematik ya da fizik öğretmeni de öğrencinin iyi bir vatandaş olmasından, demokratik, milli, manevi ve evrensel değerleri benimsemesinden, insan haklarına saygılı olmasından sorumludur. $\mathrm{Bu}$ farkındalık, hizmet öncesi öğretmen yetiştirme sürecinden başlayarak öğretmenlere kazandırılmalıdır.

Sonuçlar, kıdemi 20 yıldan fazla olan öğretmenlerin eğitimin çok yönlü gelişimi sağlama ve üst öğrenime hazırlama ile ilişkilendirilen amaçlarına ulaştığına diğer öğretmenlerden daha fazla inandıklarını göstermektedir. Bilindiği gibi eğitim, sonul çıktıları çok 
uzun bir süreçte gözlemlenebilen bir uğraştır. Dolayısıyla kıdemli öğretmenler yaptıkları işin sonuçlarını daha uzun süreli olarak gözlemleme fırsatı bulduklarından eğitime daha fazla inanıyor olabilir. Kalağan ve Güzeller'in (2010) araştırma sonuçları, deneyimsiz öğretmenlerin deneyimlilere göre daha sinik bir tutum sergilediklerini göstermektedir. Sinizm, bir yönüyle örgütte yapılan işin önemine ve amacına ulaştığına inanmama durumunu da ifade etmektedir. Dolayısıyla sözü edilen araştırma sonucu ile bu araştırma bulgularının birbirini desteklediği ileri sürülebilir. Deneyimsiz öğretmenlerin eğitime inanma düzeylerini arttırmak üzere, deneyimli öğretmenlerin mentörlük yaptı̆̆ 1 bir uygulama önerilebilir. Mentör öğretmenler, deneyimsiz ögretmenlerle yaptıkları işin uzun vadede ürün vereceğini ve amacına ulaşmayan boş bir uğraş olmadığını kendi deneyimlerine dayalı olarak paylaşabilir.

Araştırma sonuçları, öğretmenlerin eğitime inanma düzeylerinin eğitim durumlarına göre farklılaşmadığını göstermiştir. Ortalamalar gözlendiğinde, eğitim düzeyi yükseldikçe eğitime inanma düzeyinin düştüğ̈ görülmektedir. Ancak, bu değişim istatistiksel olarak anlamlı olmadığından bu konuda yorum yapmak doğru olmayacaktır. Bununla birlikte, eğitim düzeyi ile eğitime inanma arasında nasıl bir ilişki olduğu önemli bir soru olarak görülebilir. $\mathrm{Bu}$ araştırmanın sınırlılıklarından biri, örneklemde eğitim düzeyine ilişkin grupların dengesiz dağılmasıdır. Bir başka sınırlılık da alınan lisansüstü eğitimin hangi alanda olduğunun sorgulanmamasıdır. Eğitim düzeyi ile eğitime inanma arasında nasıl bir ilişki olduğu sorusuna yanıt bulmak üzere, gruplar arasındaki dağılımın daha homojen olduğu bir örneklem alınabilir. Diğer taraftan, bu konuda yapılacak araştırmalarda alınan eğitimin niteliği de dikkate alınmalıdır. Örneğin, eğitim bilimleri alanlarında yapılan lisansüstü eğitim, eğitime inanma ile daha yakından ilgili olabilecekken, temel bilimlerde yapılan yüksek lisans eğitime inanma değişkenini etkilemeyebilir.

Yöneticilik deneyimi olan öğretmenler eğitimin bireysel farkll1ıklar ve üst öğrenime hazırlama ile ilgili amaçlarına ulaştığına diğer öğretmenlere göre daha fazla inanmaktadır. Yıldırım'ın (2011) araştırmasına göre öğretmenler, yönetici olduklarında eğitim sistemini daha iyi anladıkları ifade etmektedir. Aynı öğretmenler, yönetici olduklarında sorunlu öğrencilerle baş etmeyi öğrendiklerini, çok yönlü düşünebildiklerini, olaylara olumlu bakabildiklerini ve genel olarak eğitimciliğe ilişkin duyarlılıklarının arttığını belirtmişlerdir. İlgili araştırma ve bu araştırmanın sonuçları göstermektedir ki, yöneticilik deneyimi öğretmenlerin genel olarak eğitim sistemine ilişkin algılarını olumlu yönde etkilemektedir. Bu durumun farklı nedenleri üzerine tartışmalar yürütülebilir. Örneğin, genel olarak sistem üzerine eleştiri yapan öğretmenlerin yönetim pozisyonuna gelince daha rasyonel düşünmeye başladıkları ve var olan sisteme yönelik eleştirel bakışlarının yumuşadığı ileri sürülebilir. Çünkü her durumda ideal kararlar almak ve uygulamak oldukça zordur. Yöneticilik deneyimi olanların eğitime daha fazla inanmalarının bir başka nedeni, aslında eğitime daha fazla inanan öğretmenlerin yöneticilik pozisyonlarına talip olmaları olabilir. Araştırmanın bu bulgusunu daha ayrıntılı tartışabilmek için derinlemesine nitel araştırmalar yapılması önerilmektedir. Hem öğretmenler hem de yöneticilerin katılacağı böylesi bir araştırma daha güvenilir sonuçlar üretebilir.

Kendisini genel olarak iyimser olarak tanımlayan öğretmenler eğitimin amaçlarına ulaştığına karamsar olarak tanımlayanlara göre daha fazla inanmaktadırlar. Dember, Martin, Hummer, Howe ve Melton (1989), iyimserliği hayata ilişkin olumlu algılar ve beklentilere sahip olmak olarak tanımlamaktadır. Karamsarlık ise bunun tam tersi olarak hayatın olumsuz yanlarını görmekle ilgili bir kavramdır (s. 102). Kendilerini karamsar olarak betimleyen öğretmenler de eğitim sürecine ilişkin olumsuz algılar ve beklentiler içinde olabilirler. Diğer taraftan kendisini daha çok iyimser olarak gören öğretmenlerin eğitim sürecinin olumlu yanlarını daha çok görme eğiliminde olduğu düşünülebilir. Bir örgütün amaçlarına inanma eksikliği sinizm kavramını da çağrıştırmaktadır. Zira sinizm de örgüte karşı duyulan olumsuz duygu, düşünce ve davranışlarla karakterize edilmektedir (Stanley, Meyer ve Topolnytsky, 2005; Yetim ve Ceylan, 2011). Eğitimin amaçlarına inanmak ya da inanmamak duygu, düşünce ve davranışlarda kendini gösterebilir. Örneğin sinik bir öğretmen okuluna ve eğitim sistemine güvenmediği için eğitim sisteminin amaçlarına ulaşmadığını ya da ulaşmayacağını düşünebilir. 
Böylesi bir çıkarımı desteklemek için eğitime inanma ile örgütsel sinizm arasındaki ilişkileri irdeleyen araştırmalar yapılabilir.

Sonuç olarak, öğretmenlerin eğitime inanma düzeylerinin istenilen seviyede olmadığ söylenebilir. Batı'ya göre (2016), inanmak başarısızlığı panzehiridir. Öğretmenlerin eğitme inanmaları, daha çok çaba göstermelerine ve daha nitelikli iş üretmelerine sebep olacaktır. Bu nedenle, öğretmenlerin eğitime inanmalarının önündeki engeller tespit edilmeli ve gerekli önlemler alınmalıdır. Öğretmenlerin eğitime inanmaları konusundaki gelecek araştırmalar bu engellerin neler olduğuna ve nasıl aşılabileceğine odaklanabilir.

\section{Kaynaklar}

Akın, U. (2016). Innovation efforts in education and school administration: Views of Turkish school administrators. Eurasian Journal of Educational Research, 63, 243-260.

Akın, U. (2015). Türk eğitim sisteminin amaçları ve temel ilkeleri. U. Akın (Editör). Türk eğitim sistemi ve okul yönetimi (s. 1-26). Ankara: Pegem.

Akın, U. ve Yıldırım, N. (2015). Öğretmenlerin eğitime inanma düzeyleri ölçeği (ÖEİDÖ): Geçerlik ve güvenirlik çalişmasi. e-International Journal of Educational Research, 6(1), 70-83.

Argon, R. ve Ertürk, R. (2013). İlköğretim okulu öğretmenlerinin içsel motivasyonları ve örgütsel kimliğe yönelik algıları. Kuram ve Uygulamada Ĕ̆itim Yönetimi. 19(2), 159179.

Aydın, M. (2005). Eğitim yönetimi (7. Baskı). Ankara: Hatiboğlu.

Banai, M., \& Reisel, W. D. (2007). The influence of supportive leadership and job characteristics on work alienation: A six-country investigation. Journal of World Business, 42(4), 463-476.

Bat1, U. (2016). Kendine iyi bak. İstanbul: Alfa.

Büyüköztürk, Ş., Çakmak, E.K., Akgün, Ö.E., Karadeniz, Ş. ve Demirel, F. (2012). Bilimsel araştırma yöntemleri. Ankara: Pegem.

Dember, W.N., Martin, S.H., Hummer, M.K., Howe, S.R., \& Melton, R.S. (1989). The measurement of optimism and pessimism. Current Psychology: Research and Reviews, $8(2), 102-119$.

DPT (2006). Dokuzuncu Kalınma Planı: 2007-2013. Ankara: Devlet Planlama Teşkilatı.

Enochs, L.G., \& Riggs, I.M. (1990). Further development of an elementary science teaching efficacy belief instrument: A preservice elementary scale. School Science and Mathematics, 90(8), 694-706.

Erikson, K. (1986). On work and alienation. American Sociological Review, 51(1), 1-8.

Erjem, Y. (2005). Eğitimde yabancılaşma olgusu ve öğretmen: Lise öğretmenleri üzerine sosyolojik bir araştırma. Türk Ĕgitim Bilimleri Dergisi, 3(4), 395-417.

Eryılmaz, A. ve Burgaz, B. (2011). Özel ve resmi lise öğretmenlerinin örgütsel yabancılaşma düzeyleri. Ĕ̈itim ve Bilim, 36(161), 271-285.

Grünberg, T. (2005). Felsefe ve felsefi mantık yazlları. İstanbul: Yap1 Kredi Yayınları.

Hargreaves, A. (1998). Th e emotional practice of teaching, Teaching and Teacher Education, 14(8), 835-854.

Kalağan, G. ve Güzeller, C.O. (2010). Öğretmenlerin örgütsel sinizm düzeylerinin incelenmesi. Pamukkale Üniversitesi Ĕ̈itim Fakültesi Dergisi, 27(27), 83-97.

Kasapoğlu, H. (2016). Öğretmen adaylarının Türk eğitim sistemine ilişkin algılarının metaforlar yoluyla analizi. Kuram ve Uygulamada Egitim Yönetimi, 22(1), 59-80.

Kiraz, Z. (2014). Okullar arasındaki ayrışmanın çözümlenmesi: Çankaya örneği. Akademik Sosyal Araştırmalar Dergisi, 2(7), 72-100

Kiraz, Z. ve Dursun, F. (2015). Pedagojik formasyon eğitimi alan öğretmen adaylarının aldıkları eğitime ilişkin algıları. Mersin Üniversitesi Ĕ̈itim Fakültesi Dergisi, 11(3), 1008-1028.

Ok, Ü. (2009). Dini şemalar ölçeğinden inanç veya dünya görüşü şemalari ölçeğine. C.Ü. Sosyal Bilimler Dergisi. 33(2), 149-155. 
Quinlan, K.M. (1997). Case studies of academics' educational beliefs about their discipline: Toward a discourse on scholarly dimensions of teaching. Annual Conference of the Higher Education Research and Development Society of Australasia. Adelaide, South Australia. Retrieved January 10, 2010 from www.herdsa.org.au/.

Seeman, M. (1959). On the meaning of alienation. American Sociological Review, 24(6), 783791.

Seeman, M. (1967). On the personal consequences of alienation in work. American Sociological Review, 32(2), 273-285.

Stanley, D.J., Meyer, J.P. \& Topolnytsky, L. (2005). Employee cynicism and resistance to organizational change. Journal of Business and Psychology, 19(4), 429-459.

Şimşek, H., Balay, R. ve Şimşek, A.S. (2012). İlköğretim sınıf öğretmenlerinde mesleki yabancılaşma. Eğitim Bilimleri Araştırmaları Dergisi, 2(1), 53-72.

Tondeur, J., Hermans, R., VanBraak, J., \& Valcke, M. (2008). Exploring the link between teachers" educational belief profiles and different types of computer use in the classroom. Computers in Human Behavior, 24(6), 2541-2553.

Van Veen, K., \& Sleegers, P. (2006). How does it feel? Teachers' emotions in a context of change. Journal of Curriculum Studies, 38(1), 85-111.

Weber, B.J., \& Omotani, L.M. (1994). The power of believing. Executive Educator, 16(9), 3538.

Yetim, S.A. ve Ceylan, Ö.Ö. (2011). Örgütsel sinizm ve örgütsel vatandaşlık davranışları arasındaki ilişkiyi belirlemeye ilişkin bir araştırma. E-Journal of New World Sciences Academy, 6(1), 682-695.

Yıldırım, N. (2011). Yöneticilik görevinin okul müdürlerine olumlu ve olumsuz katkıları. Eğitim ve Bilim, 36(161), 230-245.

Yılmaz, K., Altınkurt, Y. ve Çokluk, Ö. (2011). Eğitim inançları ölçeğinin geliştirilmesi: geçerlik ve güvenirlik çalışması. Kuram ve Uygulamada Ĕ̆itim Bilimleri, 11(1), 335350.

Yılmaz, S. ve Sarpkaya, P. (2009). Eğitim örgütlerinde yabancılaşma ve yönetimi. Uluslararası Insan Bilimleri Dergisi, 6(2), 314-333.

\section{Extended Abstract}

\section{Introduction}

Believing in something could be considered as a perspective towards life (Ok, 2009), a universal acknowledgment (Grünberg, 2005). When teachers believe in what they are doing, they can affect students' learning in a positive way (Weber and Omotani, 1984). When a teacher enters her or his classroom, $\mathrm{s} /$ he should believe in the first place that the lecture to be delivered and the pertaining activities serve a purpose. Thus, the teacher will ensure her or his motivation; and then motivate the student to participate in the lesson and the activities. That is because it appears to be quite difficult for a teacher who does not believe in what $\mathrm{s} / \mathrm{he}$ is doing to convince the student to believe in it and constitute the desired educational atmosphere.

One aspect of the belief in education can be addressed in relation to the nature of the teaching profession. Argon and Ertürk (2013) report that the teachers' belief that their job is respectable and worth doing is an important factor increasing their internal motivation. According to van Veen and Sleegers (2006), teachers' views regarding their profession have an important impact on their overall state of well-being. As is indicated by Hargreaves (1998), good teaching can be delivered with positive feelings. However, previous studies suggest that teacher candidates in Turkey have negative perceptions about the Turkish education system even in their pre-service training (e.g. Kasapoğlu, 2016). In a similar fashion, school managers also think that the reform efforts in the education system are not properly managed and in a sense, the work done and the efforts put in do not reach their aim (Akın, 2016).

The objectives of an organization constitute the raison d'être of that organization (Aydın, 2005). Building on this fact, believing in education is conceptualized in this paper as the 
belief that educational organizations achieve their set objectives. In other words, it was assumed that the teacher who believes the set objectives of the education are achieved believes in the education system, in short, believes in education. Education has many objectives determined over a period as long as the humanity's journey in history. While the objectives of the Turkish education system are outlined in the Basic Law of National Education No. 1739; there are also determining statements around the objectives of our education system in many other legal texts. Moreover, local and universal values that are not reflected in legal texts, the innovation brought by the rapid advances in information and communication as well as the corresponding new responsibilities have integrated and are still integrating many new and different aims into our education system. The teachers' belief that all these objectives are achieved along the process of education taking place in our schools will contribute to connecting their job directly with the students' development. Such a connection made between the work done and the outcome will then contribute to mobilization of teachers, engagement in self-sacrifice, adoption of their jobs, and professional development. In this respect, the lack of teachers' belief in the objectives of education can be considered a major problem in terms of the effectiveness of educational organizations.

The aim of this research is to determine the teachers' level of believing in achieving the educational objectives and analyze this in terms of various factors that are thought to differentiate their believing in education. In this regard, answers to the following questions were sought:

1. How much do the teachers believe that the education achieves its set objectives?

2. Does the teachers' level of belief that education achieves its set objectives differ depending on independent variables (level of school, seniority, level of education, having experience as an administrator, and being pessimistic / optimistic)?

\section{Method}

A quantitative method was adopted in the research and the study was designed in line with the survey model. The study data were collected from teachers working at public primary and secondary schools in Tokat. The study involved 546 teachers who worked in the specified schools and volunteered to take part in the study. Two hundred and forty-seven of the participants work at elementary schools (114 from primary schools +133 from middle schools), and the remaining 299 work at high schools. The seniority of 169 teachers ranged between 1-10 years, 123 had a seniority of 11-15 years, 123 had a seniority of 16-20 years, and the remaining 131 had seniority of 21 years and above. In terms of the level of education of teachers who participated in the study, 56 had done a foundation degree; 423 had a bachelor's degree and 67 had a master's or PhD degree. One hundred and seventy-five of the participants had managerial experience. Fifty-two of the teachers generally described themselves as rather pessimistic.

\section{Results and discussion}

The teachers believe that the education achieves its socialization, multi-faceted development, and preparing to upper education at medium level while they hardly believe that the objective around individual differences is achieved. When all dimensions are assessed together, the teachers believe the most that the students are prepared for higher education in the best possible way. Turkish education system is, on a large scale, a test focused system. Although government plans to decrease the importance of test scores in the system (DPT, 2006), country wide examinations are still critical for students. Such a system brings many problems together like destructive competition among students. Another prominent result of the study is that primary school teachers believe that the education achieves its set objectives more than secondary and high school teachers. This result may originate from the fact that primary school teachers spend more time with the students and find an opportunity to observe the students' development process. Moreover, teachers believe that students are given equal opportunities at the minimum level. Giving equal opportunities for all students is a basic principal of Turkish education system. But it is possible to argue that children especially living in disadvantaged regions such as villages and slums are benefitting from education services like wealthy ones in an equal way 
(see Akın, 2015, pp. 13-14). An effective solution for this problem may be government's taking more responsibility on financing education. The results show that teachers with more than 20 years of seniority believe that the education achieves its objectives of providing a multi-faceted development and preparing to upper education more than other teachers. This may be caused by the fact that senior teachers have an opportunity to observe the results of their work for a longer period of time. The study results showed that the teachers' belief in education did not differ according to their level of education. Teachers with managerial experience believe that the education achieves its objectives around individual differences and preparing to upper education more than other teachers. According to the study by Yildırım (2011), teachers understand the education system better when they become managers. The same teachers indicated that they learned how to deal with troubled students, became capable of thinking multi-dimensionally and seeing events positively, and increased their awareness around being an educator when they became managers. The results of the respective research and this research show that managerial experience generally affects the teachers' perceptions of the education system positively. Teachers who describe themselves as optimistic believe that the education achieves its objectives more than those that describe themselves as pessimistic. Dember, Martin, Hummer, Howe and Melton (1989) define optimism as having positive perceptions and expectations about life. Pessimism on the other hand is the exact opposite of this; a concept related to noticing the negative aspects of the life (p. 102). Teachers who describe themselves as pessimistic may have negative perceptions and expectations about the education system. On the other hand, teachers who consider themselves rather optimistic may have a tendency to see the positive aspects of the education system more than the negatives. 